\title{
Research Square \\ Nummular Headache - A case report of a rare entity
}

\section{Davis Thomas ( $\nabla$ davisct1@gmail.com )}

Pervyj Moskovskij gosudarstvennyj medicinskij universitet imeni I M Secenova Stomatologiceskij fakul'tet

\section{Gary M. Heir}

Rutgers The State University of New Jersey

\section{Amey G. Patil}

Rutgers The State University of New Jersey

\section{Prutha K. Soni}

Rutgers The State University of New Jersey

\section{Case report}

Keywords: Nummular headache, Rare primary headaches, Coin-shaped headache, Chronic Primary headache, Epicranial headache

Posted Date: June 19th, 2020

DOI: https://doi.org/10.21203/rs.2.23624/v2

License: (c) (i) This work is licensed under a Creative Commons Attribution 4.0 International License. Read Full License

Version of Record: A version of this preprint was published at Current Pain and Headache Reports on October 12th, 2020. See the published version at https://doi.org/10.1007/s11916-020-00901-8. 
The authors have withdrawn this preprint from Research Square 